\title{
Timeline from the Foundation of Regional Technical Colleges in Ireland to the Emergence of Technological Universities
}

\author{
Lynne Whelan, Carmel Maher, Colin Deevy \\ Institute of Technology Carlow, Ireland
}

\begin{abstract}
The research work is focused on a Masters by research entitled 'The Role of Practice Oriented Learning in Design \& Creativity in an Irish Technological University'. The research sits within the context of the discipline of design within the emerging Technological University (TU). The project began with the development of a contextual timeline. This timeline captures and illustrates the development of the Irish Educational System from the emergence of Regional Technical Colleges through to the developing Technological Universities. Education in the higher sector in Ireland is inextricably linked to economic progress and throughout the timeline, a clear mirroring of economic drivers, influences and impacts can be witnessed on the technology sector education. The challenge for the next stage is in retaining the effective social and cultural values associated with technical education in Ireland whilst creating a future response to global competitiveness. The gap in the knowledge identified in the research to date is in the means of achieving this.
\end{abstract}

\section{Introduction}

Society is witnessing a paradigm shift in the drivers of economics. We are moving from the industrial age of production economy, to the knowledge age of innovation-based economy. The European Union recognise education as being pivotal in creating a knowledge-based economy. In Ireland, the Department of Education is responding to the drivers and has created and begun implementation of, a National Strategy to 2030 in Higher Education also known as The Hunt Report. The role of teaching and learning is being reviewed and attempts are being made to promote a climate of innovation and innovative thinkers for Ireland's future workforce. The aim being to achieve an innovation-based economy, growth and a competitive edge within EU and global markets.

In order to assist with our understanding of the strategy for our developing Higher Education sector, a contextual timeline was developed (see Figure 1). The context covers policy, social and fiscal influences on an EU and National framework which assists our understanding of the strategy for our developing Higher Education sector. This paper outlines and reflects on the significant events on this timeline which spans the development of the Irish Educational System from the emergence of Regional Technical Colleges through to the developing Technological Universities The timeline charts firstly, economic drivers from T.K. Whitakers first programme for economic expansion 1958 through to the launch of the action plan for jobs by Dept. of Jobs Enterprise and Innovation 2012. It marks a shift in economic drivers from a post-production economy to knowledge innovation-based economy. Secondly the timeline maps the development of the technology sector in higher education in Ireland from Mulcahys [10] report on the development of Regional Technical Colleges through to the Hunt [7] report on current higher education strategy including the emergence of Technological Universities. The Hunt report promotes the creation of an innovative workforce to meet the demands of the economy. The timeline illustrates how a correlation between economic demands and educational strategy has and continues to be intrinsic to the model of technical education that exists in Ireland.

Having a future strategy for higher education in Ireland is therefore important, however, how it is interpreted, applied and implemented is equally important. Past methods of teaching and learning were primarily aimed at addressing industrial production. In order to address todays demand for rapid knowledge-based innovation, a new approach may be needed.

Currently the underlying concerns within the collegiate realms throughout the transition from IOT's to TU's, are the over influence of commercial drivers, the risk of funding cuts, efficiency drives, all within the face of higher participatory rates. The challenge therefore for the next stage is in retaining the effective social and cultural values associated with technical educational in Ireland whilst creating a future response to global competitiveness. The gap 


\section{Timeline The Emergence of R.T.C.'s \& Development towards Technological Universities}

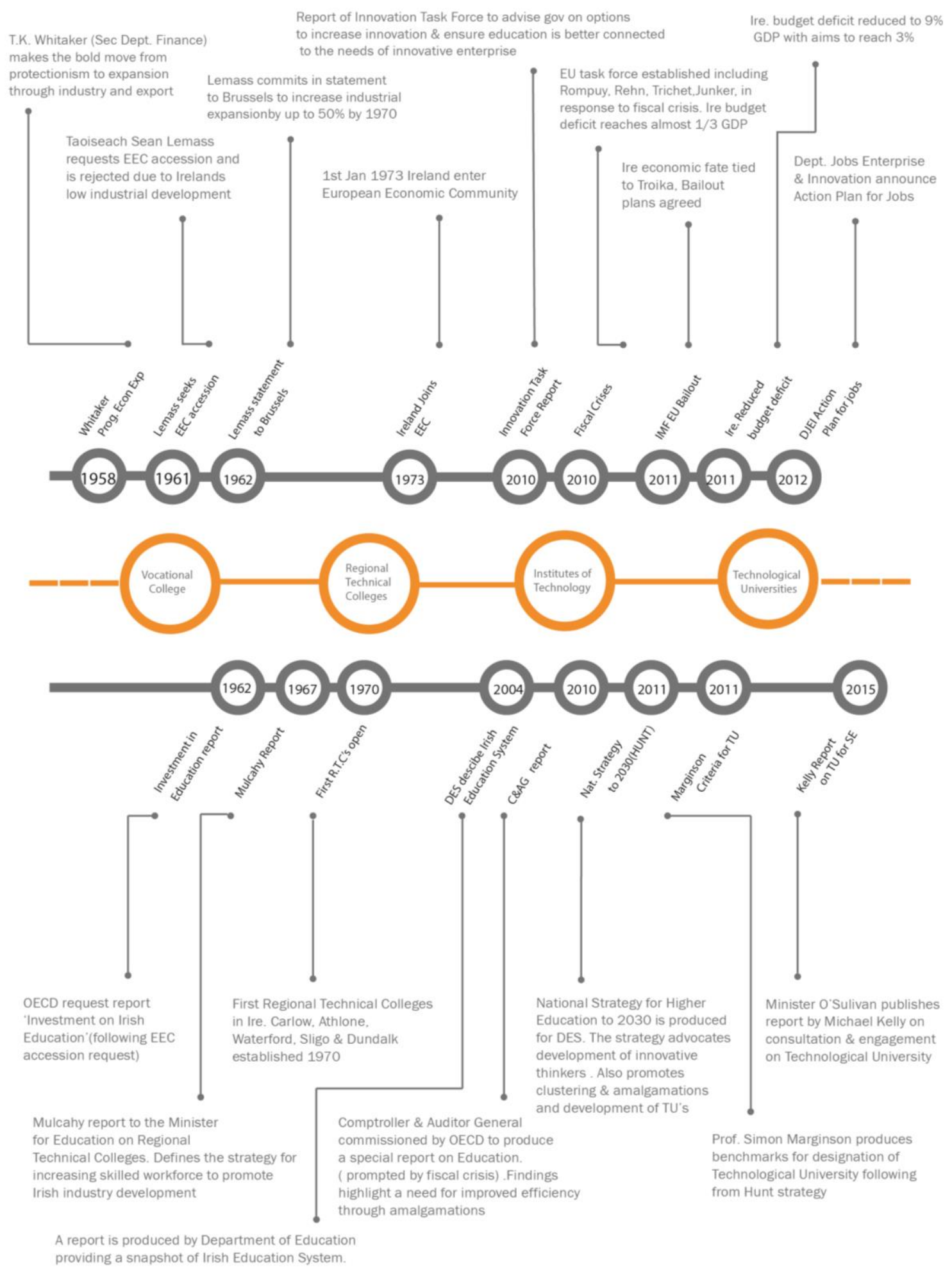

Figure 1. Timeline 
in the knowledge identified through the research to date is in the means of achieving this.

\section{Strategies of Irish Higher Education}

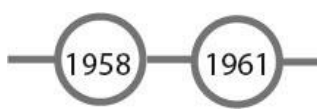

In order to explore the changing strategies of Irish higher education, a visual timeline was created (See Figure 1.) which spans the period from 1958 to the present. It is through this journey that we uncover the rationale behind the emergence of Regional Technical Colleges and the development of the Technological Universities.

In understanding the initiative for developing technical colleges in Ireland we must start our timeline with a look back to the first programme for economic expansion 1958, driven by the vision of T.K. Whitaker which marks the beginning of Ireland's industrial capacity being realised. The GDP which averaged 1\% throughout the previous decade, had reached 5\% by 1960 [8] .It was through this development that Ireland was in a position to apply for accession to EEC to avail of European integration and most importantly open markets. Ireland had for many years availed of open markets with the UK and were now in a position to seek the larger benefits of joining the open markets of Europe. Ireland had begun application for accession to EEC in July 1961 which was rejected.

"'I have the honour, on behalf of my government, to inform Your Excellency, that Ireland desires to become a member of the European Economic Community', [8]

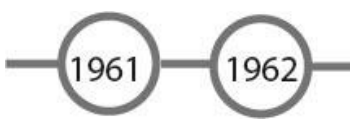

A following statement to Brussels on application to EEC by Irelands then Taoiseach Sean Lemass in 1962 acknowledges that agriculture is classed as the main economic significance to Ireland.

"Agriculture ...has a particularly important place in our economy. It generates about one-quarter of the national income, employs over one-third of the gainfully-occupied population and it is responsible .... for three quarters of our exports [8].
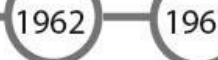

However, Lemass continues that it is highlighted that Ireland's strategy is for an increase in industrial production. The aim is to increase industrial production in line with existing EEC members and that Ireland has the capacity to achieve this. '.... total increase in production of $50 \%$ by 1970 is within the capacity of the Irish economy, Ireland can reach the collective target ....set by ... Organisation for Economic Cooperation and Development (OECD)' ${ }^{\prime}$ [8] . This highlights the beginnings of Ireland's relationship with OECD and our alignments to EU targets which continues today. The primary driver for economic expansion was the desire to join the expanding EU open market and increase Ireland's industrial production to capitalise in doing so and to meet with OECD targets for members.

'Investment in Education' was a pilot study , commissioned by Dr Patrick Hilary Minister for Education, driven by Lemass, initiated by OECD the same year that Lemass put forward the statement to Brussels for accession to EEC. Europe and Ireland recognised the need to create the future work force for industrial expansion through improved educational strategies.

' 'Investment' (report) offered the essential rationale and blueprint for the transformation of the Irish educational system" [12]. The following decade saw the introduction of free education in Irish secondary schools, the publication of the 'The Steering Committee on Technical Education' also known as the Mulcahy Report and the opening of the first Regional Technical Colleges in Ireland.

The Mulcahy report was published in 1967 and clearly identifies the necessity of trained technical personnel in order to promote industrial development and how Ireland to date has not achieved this.

" the availability of increased technical knowledge and skill...is necessary...for further economic growth and the promotion of innovation and enterprise ... Ireland has largely failed to provide this" [10].

Interestingly, Mulcahy also points out the difference between need and demand. Irish education has never developed in this way before. The people themselves are not creating a demand for education but rather the government has recognised the need for a technically trained work force for the reasons of economic development.

"if the demand for needed skills does not arise naturally, it must be stimulated artificially" [10].

The Regional Technical Colleges were seen as a solution. Leaving cert courses were also considered as provision in the R.T.C's as a means of creating a greater transition to Higher Education at the early stages. Mulcahy and his committee now had to go about the task of assessing the current state of play and formulating a strategy to advise the Minister for Education, Donagh O'Malley, on technical education in Ireland.

Ireland was admittedly somewhat behind in relation to UK and Europe with regards its natural industrial development. 
' ...for historical reasons, the industrial development of Ireland was retarded until well on in the present century"' [8].

The reasons for Irelands lack of industrial development is seen by some as the result of British rule. However, there would appear to be several contributing factors such as the Act of Union 1801 and the leap forward in transportation such as steam ships and railways. Both of these factors created a free market for trade between Ireland and Britain and through Britain to international markets. Daly [4] notes that a competitive market realises the most successful industries to the top and that this was the case in relation to Ireland, namely that it could not compete with British industry.

"the law of international comparative advantage dictates that when the single market came into being those Irish industries inefficient by British standards would be wiped out by their more efficient British counterpoints", [5].

Ireland was competitive in a few specialised area which were successful such as the linen industry in NE Ulster, Harland \& Wolf shipbuilders, Guinness brewery Dublin. Overall however it could be said that Ireland was in effect overshadowed by the industrial giant that Britain had become. It could equally be argued that the original cause of our inability to compete stems from the impact of previous generations of British rule.

The outcome remains the same; Ireland is behind the EEC members in industrial production which is recognised as key to economic development and therefore strategically must invest and drive forwards our industrial development including a technically educated and skilled workforce. The strategies which emerged were to cover general education subjects but also to include theoretical with the practical experience. There would be an input of skill knowledge, practice and theory in varying amounts depending on the trade. Nonetheless the main aim was always; to educate people from craft level to professional level in order to provide an industrial workforce.

" the main long-term function... will be to educate for trade and industry...concerned with providing industrial manpower, particularly in the technician area" [10].

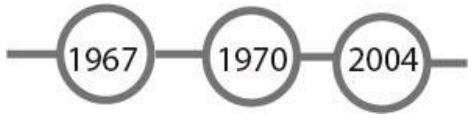

It was well recognised by Mulcahy that the committee was not in a position to quantify much of the future projections with the information available. The overall strategy put forward was for flexibility and most importantly the provision for growth. The committee actually requested the minister to provide outside consultancy to evaluate the demand for places in R.T.C's. It was envisaged that some of the newly trained workforce would possibly travel abroad to find work and that it would be difficult to balance requirements against uptake and employment potential.

Mulcahy did embrace some forward-thinking strategies and advised that colleges should not fall in to 'fixed patterns' but should be flexible to the needs of society, economy and regional industry. This thinking is as relevant today within the discussions of the developing Technological Universities in Ireland and the future strategies they will adopt albeit with an extended international and global market approach.

The decade between the early sixties through to early seventies in Ireland saw the vision of TK Whitakers free trade and move away from protectionism propel Ireland in a move from agriculture to industry and the creation of modern Ireland. The logistics of creating a technological industrial economy required a skilled labour force that emerged under the advice of Mulcahy and the Steering Committee, in the form of the Regional Technical Colleges (R.T.C's) throughout Ireland.

\section{Development towards T.U.'s}

The emergence of R.T.C's clearly mirrored an economic demand which has continued throughout the development and transitions that technical education in Ireland has witnessed to the current day. This is reflected in the Hunt report.

"higher education will play a central role .... for innovation, competitive enterprise...." [7].

Mulcahy's view of the Institutes as a flexible educational provider which 'must be capable of continuing adaptation to social, economic and technical changes', has remained relevant as we witnessed the Regional Technical Colleges adopt the titles of Institutes of Technology in the mid 1990's. This reflects the broadening, global markets that opened up as a result of the digital information technology boom which meant the Institutes had a wider impact on teaching and learning than a regional response as reflected in this name change. At this point in mid-1990's, Ireland's economic growth is reaching unprecedented levels as employment soars to 1.9 million and the country booms in what became known as the 'Celtic tiger'. The economic success also saw Ireland openly acknowledge the value that is now placed on education. When we consider Mulcahys advice on having to artificially stimulate the demand for higher education we can mark the significance of this as a societal shift. It becomes recognised that previously held ideas of class distinction being the differentiator, no longer remains the case, that actually it is now the level of education attained that sets a person apart, regardless of social background. 
Conor Lenihan, the then Minister for Science, Technology and Innovation, in the Oireachteas debate 1999 notes:

"Education is the benchmark of progress in society... societal theorists have moved from that old Marxist perception and now hold the view that educational attainment is what designates a person as advantaged or disadvantaged .... this indicates an important shift in thinking in liberal democratic states" [9].

\section{$2010-2011$}

The most significant impact however has come in more recent years as Ireland and indeed Europe responds to a fiscal crisis. By 2010 the budget deficit in Ireland is up to a third of GDP [1], this, the cost of bailing out Irelands banking system. Ireland faces economic collapse and with it harsh austerity measures. The bank debt added to an already substantial budget deficit meant that public services would require an 'abrupt adjustment'. This was to have significant impact on all sectors including education. It is no coincidence therefore that a special report by the Comptroller and Auditor General(C\&AG) was published for the Department of Education and Skills in the same year. The conclusions drawn from the audit and evaluation of Higher Education by C\& AG, very clearly advise for more collaboration:

" similar projects were funded ... leading to a risk of overlap....aim of the programme was to induce a greater level of collaboration between institutions" [2]. There is also a proposal that future funding will be based on 'viable' proposals with more measurable outputs. It is unambiguously linking collaborations and measurable outcomes with efficiencies albeit cautiously:

" ...the full impact of collaboration in terms of improved efficiencies...has yet to materialise.' [2]

In the same year the 'Report of the Innovation Taskforce' was published by the department of the Taoiseach. The report was designed to inform Irish government in strategy for innovation which translates into high value jobs and sustainable growth. The strategy presented, identifies Ireland as a worldwide innovation hub and included is a number of recommendations such as, the clustering of companies and an education system that provides for an innovative economy;

"the report of the innovation Taskforce sets out a strategy for positioning Ireland as an International Development Hub.... (with) an education system that is better connected with the needs of innovative enterprises" [11].

The National Strategy for Higher Education to 2030, published by Irish Department of Education and Skills, also known as Hunt Report, was being prepared at the same time and published in 2011. The Hunt report responds to and articulates the strategies of these government reports into an educational context. It is not surprising therefore that clustering, amalgamations, consolidations, are top of the agenda.

The recommended consolidations involve not only the education providers but also the bodies under the Aegis of Department of Education such as the Higher Education Authority (HEA). To date, since the 2004 report [6], the Bodies under the Aegis of the Department have been amalgamated from 27 to 16 .

'a reformed higher education authority should collectively meet the national priorities, without wasteful duplication '[7]. The proposals for 'clustering' which we have noted from the C\&AG and Innovation Taskforce reports is also presented in the Hunt report in the recommendations for the educational providers:

'systems should be strengthened by development of regional clusters of collaborating institutions' [7]. The emphasis however, the Hunt report places on the need to consolidate, is for enhancement rather than purely efficiency driven:

'...the emergence of stronger amalgamated Institutes of technology..' [7]. However, the overall strategy for amalgamation would appear to be in order to recognise the naturally occurring change within Higher Education to meet the demands for higher levels of education provision, for higher participatory levels. It is clearly interpreted by Hunt, the need to respond to an innovative economy through education to 'provide sustainable employment opportunities'. In order to provide sustainable employment opportunities, in transitioning from Institute of Technology to Technological University, it must reflect the global shift from technology production driven economy to the knowledge based innovative economy.

In 2011 Ireland receives $€ 85$ billion in the form of a bailout from EU International Monetary Fund (IMF). The following year saw Irish people face huge austerity measures, but the results were, according to European Commission; that policy conditions were substantially met, and investor confidence restored. Ireland could begin to rebuild its economy and whilst doing so take the opportunity to assess and re strategize going forward. The government introduced the 'Action Plan for Jobs 2012' initiative which was produced by the Department of Jobs Enterprise and Innovation. The Action plan strategic ambition is for job creation, increase ranking in International competitiveness, stimulate employment in locally traded sectors, increase exports and build world class clusters in sectors of opportunity. By 2013 Ireland was in the position to officially exit the bailout. By 2014 the Department for Jobs Enterprise and Innovation 
(DJEI) produce a report of the Entrepreneurship Forum entitled 'Entrepreneurship in Ireland Strengthening the Start-up Community'. Funding is becoming available for Start-ups and SME's are seen as a future model for Ireland's competitive edge on innovation. The culture for funding entrepreneurs is nurtured with opportunities through Enterprise Ireland, reflecting the shift in economic drivers towards innovation.

The economic strategy and collegiate realms share the vision of the future H.E. as globally competitive, knowledge and innovation based. The C\&AG, DJEI, Enterprise Ireland, all aim to increase entrepreneurship and innovation to assist with job creation and global competitiveness in a knowledgebased economy. The development of knowledge creation in an educational context has been proposed through the National strategy to 2030, the Hunt report. It also proposes to streamline, uniform and consolidate higher education. However, this may be counterproductive to achieve innovative and critical thinkers requires for knowledge creation. There is a dichotomy of thinking between what is hoped to be achieved and how it may be achieved. The method therefore of how to achieve the desired outcomes has been identified as the gap in the knowledge (see Figure 2).

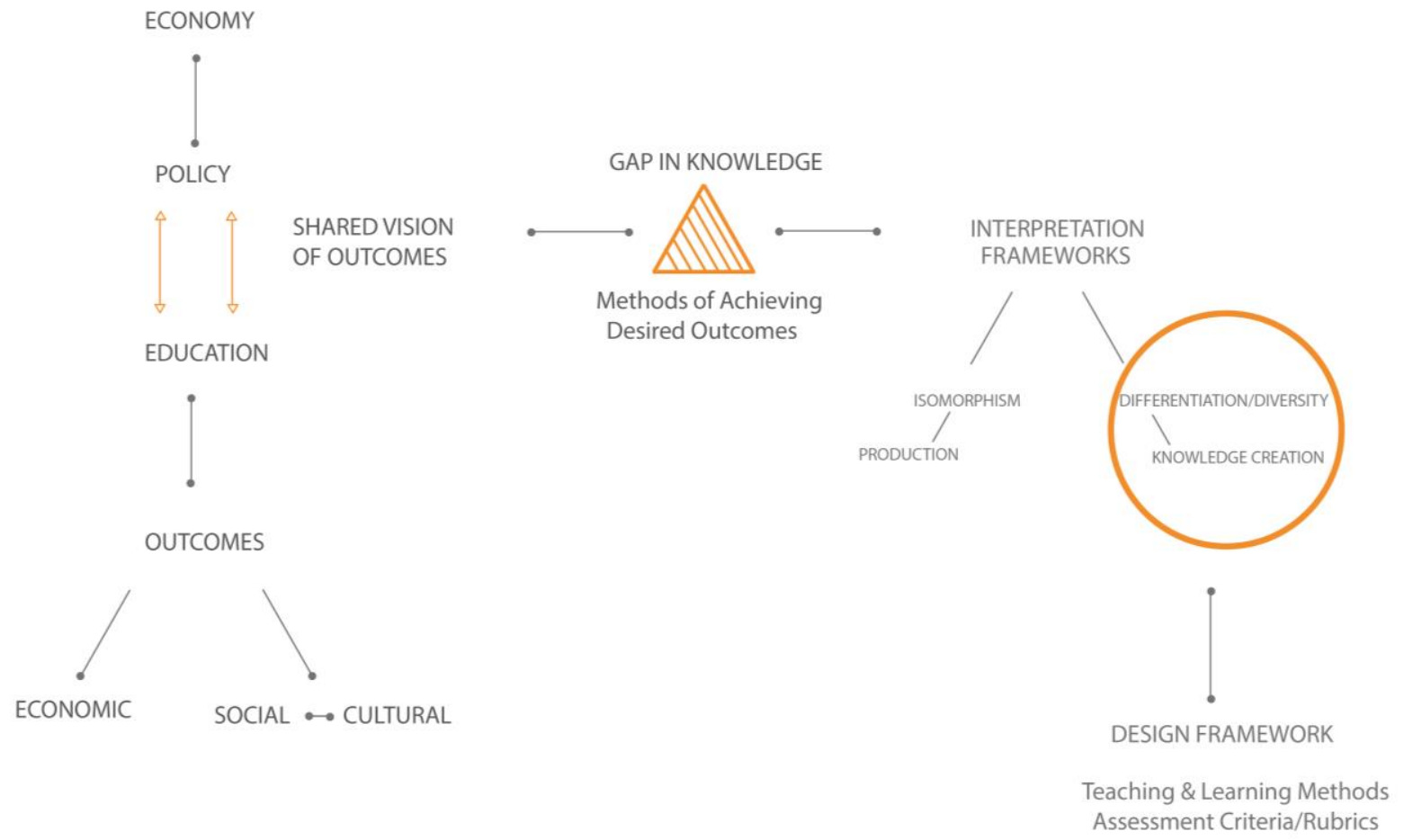

Figure 2. Gap in the Knowledge

As the collegiate realm defend the possibility of imposition of change which may have unintended consequences, coming from the top down. It is equally important that the collegiate realm step forward with frameworks and proposals from the bottom up. This will assist with informing and addressing the current gap in the knowledge as to the methods of achieving the shared vision and desired outcomes for Ireland's H.E. Sector. In response to this the research question going forward is "What is the role of practice-based learning as a method of addressing social, cultural and economic aims for knowledge creation in an educational context? Equally important will be the focus on methods of assessment. The project position has been mapped within this broader context of the knowledge transfer cycle (see Figure 3). 


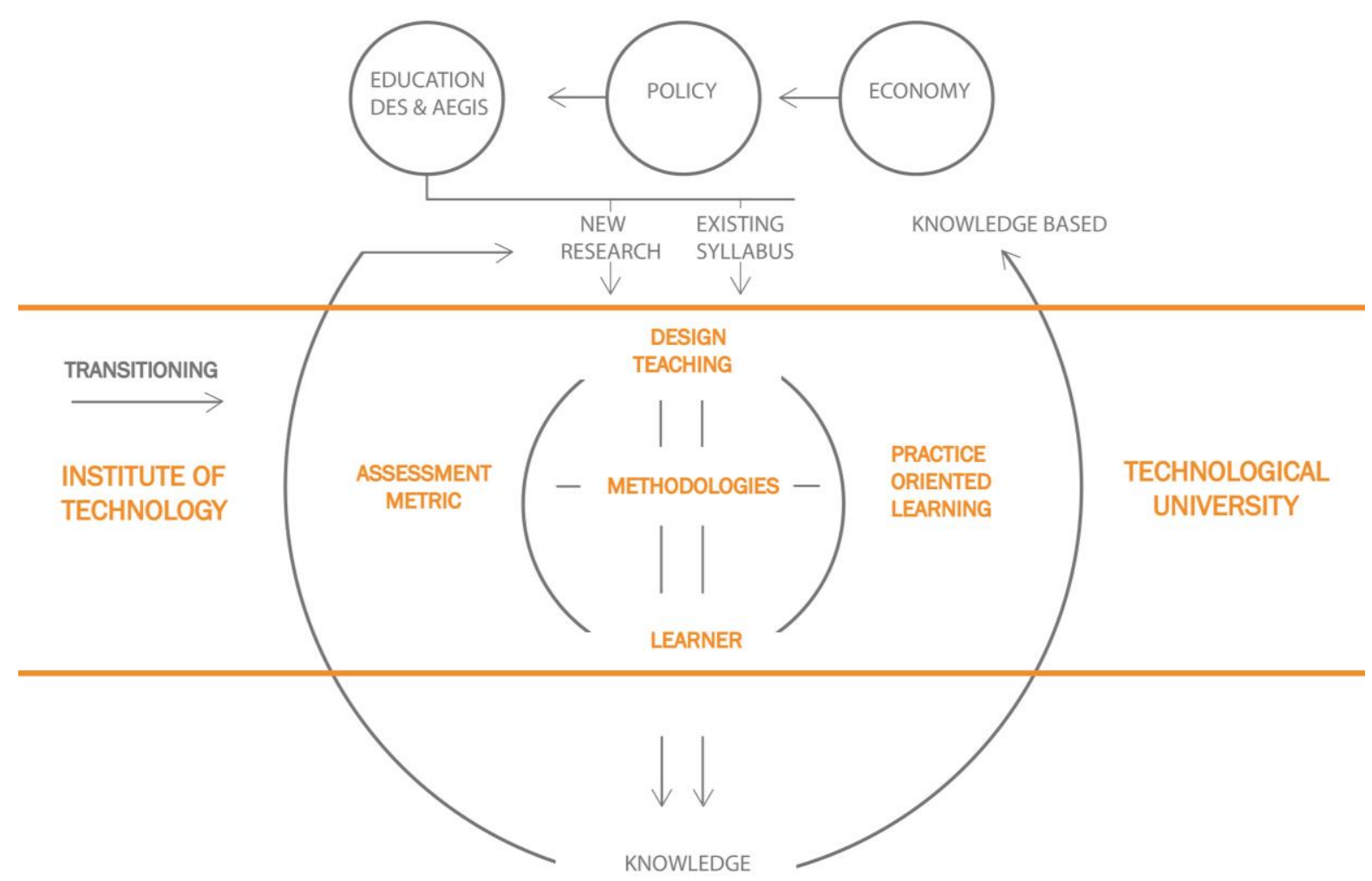

Figure 3. Research Project Positioning within the broader knowledge transfer cycle

\section{Conclusion}

The timeline which we have explored has uncovered the rationale and macro influences on our developing Higher Education sector. As Whitaker drove forward Irelands industrial production, so Mulcahy forged the strategy for developing Regional Technical Colleges to meet the demands of an industrial workforce. Ireland's economy boomed and as it did so, it was recognised by Irish government that education had become the benchmark for societal esteem as opposed to class distinction marking a shift in thinking and bringing education back as a core value in society and accessible to all.

The fiscal crisis in recent years has created the risk of eroded quality through efficiency drives but could also been seen as an opportunity for re strategizing. The current strategy for Higher Education to 2030 strives to create a balance between investment priorities and the increasing participatory levels, whilst ensuring quality in research teaching and learning. The aims of investment streams is to create a workforce suitable for a new innovation based economy, mirrored in the aims of Higher education strategy for the development of creative innovative thinkers. The gap in the knowledge would appear to be the methods applied to achieving the aims of both the investment streams and Higher Education. It is recognised that knowledge transfer requires a broader and deeper concept than technology transfer and therefore the methods of both pedagogy and assessment must reflect this. The experience, culture and ethos developed since emergence of R.T.C's has a recognised value. It must be a combined top down, bottom up approach in achieving the desired outcomes. Education in the higher sector in Ireland is inextricably linked to economic progress. The challenge therefore for the next stage is in retaining the cultural values associated with Technical educational in Ireland whilst creating a future response to global competitiveness. As difficult a task as this may seem it would be no less relevant to draw a reminder from the beginning of our timeline and T.K Whitakers original vision and founding ethos that saw the emergence of modern Ireland:

"Let us remember that we are not seeking economic progress for purely materialistic reasons but because it makes possible relief of hardship and want, the establishment of a better social order, the raising of human dignity, and, eventually, the participation of all who are born in Ireland in the benefits, moral and cultural, as well as material, of spending their lives and bringing up families in Ireland" [13] 


\section{References}

[1] BBC 2015 'Ireland profile from the section Europe' online resource http://www.bbc.com/news/world-europe17480250 (Access date 25 September 2015).

[2] C\&AG 2010 'Comptroller \& Auditor General Special Report for Department of Education \& Skills' Pub. Gov. of Ire. 2010.

[3] Chambers A. 2014 'Portrait of a Patriot' Published Doubleday, Ireland 2014.

[4] Daly 1981 Referenced in Davies G. 1992 P.57 online resource www.tcd.ie/Economics/assets/pdf/ (Access date 17 November 2015).

[5] Davies G. 1992 P.57 online resource www.tcd.ie/Economics/assets/pdf/ (Access date 17 November 2015).

[6] DES 2004 - Department of Education \& Science, 'A Brief Description of Irish Education System 'Published by Communications Unit Department of Education \& Science 2004.

[7] Hunt C. 2011 'National Strategy for Higher Education to 2030 'Published by Dept. of Education and Skills Ireland 2011.

[8] Lemass S. 1962 'Statement to Brussels 1962 'online resource http://www.cvce.eu/obj/statement_by_sean_ lemass_brussels_18_january_1962. Publication date: 21/10/2012 (Access date 16 November 2015).

[9] Lenihan C. 1999 'House of the Oireachteas debates' online resource http://oireachtasdebates.oireachtas.ie/ debates\%20authoring/debateswebpack.nsf/takes/dail19990 61600026?opendocument (Access date 08 December 2015) .

[10] Mulcahy N. 1967 'The Steering Committee on Technical Education' Pub: The Stationary Office Dublin 1967.

[11] Report of Innovation Taskforce, Government of Ireland, Published by The Stationary Office, Dublin Mar 2010 .

[12] Walsh J. 2014 et al , McCoy S., Seery A., Conway P., 'Irish Educational Studies '2014 Vol. 33, No. 2 119-122 Trinity College Library July 2014.

[13] Whitaker T.K Reference Chambers A. 'Portrait of a Patriot' Published Doubleday, Ireland 2014. 